SOPHE Corner

Daniel P. Perales, DrPH, MPH, CJHP Associate Ed

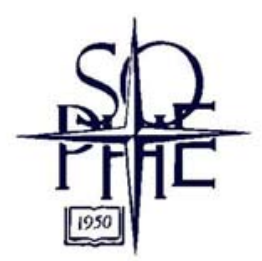

\title{
Contents
}

1. SOPHE 57 ${ }^{\text {th }}$ Annual Meeting: Nov. 2-4, 2006 in Boston, MA,

\section{Call for SOPHE Awards}

3. Openings: SOPHE Committees

4. Join SOPHE

SOPHE 57th Annual Meeting, November 2-4, 2006 in Boston, MA. "Health as a Human Right: Health Education, Equality, and Social Justice for All"

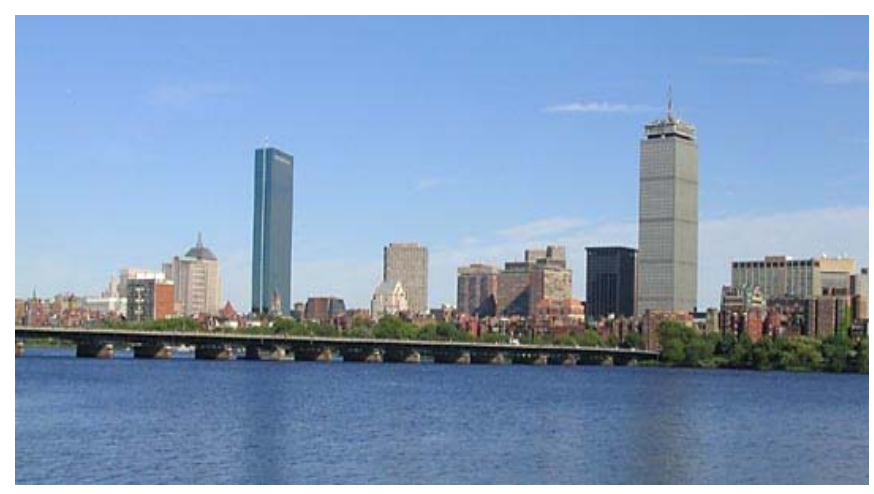

SOPHE's 2006 Annual Meeting will examine the impact of reciprocal influences of health and human rights, including the impact public health programs and policies have on human rights and health disparities, the consequences human rights violations have on health, the importance of health in realizing human rights, and the ways in which health educators can ensure that human rights are integrated into public health strategies to eliminate disparities.

Online registration will be available late this summer. Please access the SOPHE website for the latest information at: http://www.sophe.org/index.asp

\section{Call for SOPHE Awards!: Deadline July 31 ${ }^{\text {st }}, 2006$}

Distinguished Fellow Award- This award is SOPHE's highest form of recognition for a Society member and recognizes a person who has made exemplary and lasting contributions to the field of health education. The award will be presented at the 2006 SOPHE Annual Meeting Awards Banquet in Boston, MA.

Health Education Mentor Award- This award recognizes individuals who have provided excellence in mentorship to health educators in their preparation, performance, and/or practice. It recognizes individuals who have served to successfully bridge the gap between practice and research. 
Program Excellence Award- This award recognizes outstanding contributions by a program (not an agency), in existence for at least three years, to the practice of health education. Award recipients must demonstrate systematic application of the following components:

- $\quad$ Health education principles including provision of a planned, reinforcing series of educational experiences over time;

- Involvement of the target population in planning and implementation; and

- $\quad$ A well-defined evaluation component.

Chapter Innovation Award- This award of \$250 recognizes and publicizes creative and replicable methods implemented by SOPHE chapters to deliver one or more core member services: membership; fiscal management; board and leadership development; communications; continuing education; alignment of chapter and national strategic plans; and/or bylaws and policies.

SOPHE Open Society Award - This award will be given each year to recognize an individual or group who embodies and promotes an Open Society, through research, practice, and/or teaching.

Vivian Drenckhahn Student Scholarship Award - This award of \$1500 provides support to both undergraduate and graduate level full-time students in their pursuit of educational and professional development in health education.

Graduate Student Research Paper Award - This award is designed to foster quality graduate student research and to provide a mechanism by which to recognize outstanding graduate students for creative and innovative research. The recipient of this award receives $\$ 250$ and is encouraged to submit the paper for review to SOPHE's journals, Health Education and Behavior or Health Promotion Practice.

SOPHE/CDC Student Fellowship in Injury Prevention and Control - This one-year fellowship is designed to recognize, assist and train graduate students working on research or practice-based unintentional injury prevention projects from the perspective of health education or behavioral sciences. Included is a $\$ 1500$ stipend for the student's special project, one-year SOPHE membership, complimentary annual meeting registration, and an opportunity for an oral or poster presentation about the project at the 2007 SOPHE Annual Meeting in Washington, DC.

SOPHE/ATSDR Student Fellowship in Environmental Health Promotion - This one-year fellowship is designed to recognize, assist and train students working on research or practicebased environmental health education/health promotion or environmental justice from the perspective of health education or behavioral sciences. Included is a \$1500 stipend for the student's special project, one-year SOPHE membership, complimentary annual meeting registration, and an opportunity for an oral or poster presentation about the project at the 2007 
SOPHE Annual Meeting in Washington, DC.

Nomination packets for these awards are available from the National SOPHE office or can be accessed via SOPHE's web-site at www.sophe.org/content/awards.asp. A complete nomination packet includes an application form, cover letter from the SOPHE member coordinating the nomination, and support letters from National SOPHE members in good standing (where required). All correspondence to National SOPHE should be addressed to: SOPHE Awards Committee, 750 First Street NE, Suite 910, Washington, DC 20002; (202) 408-9804.

Nominations for all awards are due July 31 of each year.

\section{Openings: SOPHE Committees}

The National SOPHE Resolutions Committee is seeking past resolution authors and new members to serve on the committee.

Duties include ensuring that action items stated in accepted resolutions are being actively pursued, reviewing new resolutions for recommendation to the Board of Trustees for adoption and updating resolutions already passed.

This is also a wonderful opportunity for authors of past resolutions to become actively involved in assuring that action items are carried out.

If you are interested, please contact any of the co-chairs:

Ann Houston ann.houston@ncmail.net

Tiffany Redding tiffani.c.redding@medstar.net or

Jody Ruth Steinhardt jody.steinhardt@verizon.net

The National SOPHE Electronic Communications Committee is in need of your help! The purpose of the committee is to support and encourage electronic communications between and among SOPHE members and chapters to pursue SOPHE's mission and Strategic Plan; to develop and support a strong SOPHE presence on the World Wide Web in such a way as to reflect and further the work of the organization; and to utilize internet technology to fundraise, communicate and advocate.

We are seeking SOPHE members to assist in many existing tasks to help the National office communicate more effectively with members and the public. Opportunities include, but are not limited to:

- $\quad$ Continuing to refine and improve the SOPHE website and develop mechanisms for member feedback; 
- $\quad$ Working with SOPHE committees, SIGs, caucuses and chapters to improve communications via the new website features;

- Developing policies concerning the integration of the SOPHE member database into the SOPHE website; and

- $\quad$ Exploring new continuing/distance education opportunities, and working to improve SOPHE chapter communications.

Sophisticated technological experience is NOT needed. If you have an opinion and constructive ideas about improving SOPHE's current website and electronic communications, and have an interest in serving the organization in a meaningful way that will benefit all SOPHE members, THIS is the committee for you.

Now is an exciting time to join this dynamic committee! If you are interested, please contact Don Chaney at dchaney@hlkn.tamu.edu or Blakely Pomietto at bpomietto@sophe.org

\section{Join SOPHE}

SOPHE is a 56 year old association whose members include more than 4,000 professionals with formal training and/or an interest in health education and health promotion throughout the United States and 25 foreign countries. Members work in schools, universities, medical/managed care settings, corporations, voluntary health agencies, international organizations, and federal, state, and local government. There are currently 25 SOPHE chapters covering 35 states. The SOPHE Mission: To promote, encourage and contribute to the advancement of health of all people through education.

If you are not already a member, please visit the following SOPHE link and read about the benefits of professional membership. http://www.sophe.org/content/member_benefits.asp

\section{Back to top of page}

